\title{
MATERIAL UTILIZATION OF WASTE ORIGINATING DURING PROCESSING OF PLANT JATROPHA CURCAS L. IN BIOCOMPOSITES - ADHESIVE-COHESIVE CHARACTERISTICS AND WEAR
}

\author{
Petr Valášek, Miroslav Müller, Alessandro Ruggiero
}

Original scientific paper

Renewable sources should be preferred by a modern society and this should be done not only in the areas of material engineering. Jatropha curcas L. is a plant with a high potential with many technologically utilized parts among which seeds most of all. The seeds of the plant serve for the pressing of oil. During this technological process worse utilizable commodities such as pressed cakes, seed shells or pressed seed kernels are gained except for primary commodities (oil). A meaningful utilization of these secondary biocommodities is the key for optimization of the whole technological process. An experiment describes mechanical properties of an epoxy resin filled with commodities from the pressing of Jatropha curcas L. treated by the mechanical milling. The epoxy resin (Glue Epox Rapid) filled with microparticles of shells $(67,8 \mu \mathrm{m})$, of seed cakes $(108,1 \mu \mathrm{m})$ and of seed kernel cakes $(82,7 \mu \mathrm{m})$ was used in the experiment.

Keywords: epoxy resin; hardness; tensile strength; utilization of waste

\section{Iskorištenje otpada nastalog obradom biljke Jatropha curcas L. u biokompozitima - adhezivno-kohezivne karakteristike i trošenje}

Izvorni znanstveni članak Suvremeno društvo bi trebalo preferirati obnovljive izvore i to bi se trebalo činiti ne samo u području obrade materijala. Jatropha curcas L. je biljka velikog potencijala s mnogo tehnološki iskoristivih dijelova. Među njima prvenstvo pripada sjemenkama. One služe za dobivanje ulja. Tijekom tog tehnološkog postupka, osim tog osnovnog proizvoda (ulje) dobivaju se i slabije iskoristivi materijali kao sprešani talog, ljuske sjemenki ili sprešane jezgre sjemenki. Korisna uporaba tih sekundarnih bioproizvoda predstavlja ključ za optimizaciju čitavog tehnološkog postupka. Eksperiment pokazuje mehanička svojstva epoksidne smole ispunjene proizvodima dobivenim prešanjem Jatropha curcas L. obrađene mehaničkim drobljenjem. U eksperimentu je upotrebljena epoksidna smola (Glue Epox Rapid) uz dodatak mikročestica ljuski $(67,8 \mu \mathrm{m})$, sprešanih sjemenki $(108,1 \mu \mathrm{m}) \mathrm{i}$ jezgri sjemenki $(82,7 \mu \mathrm{m})$.

Ključne riječi: epoksidna smola; iskorištenje otpada; tvrdoća; vlačna čvrstoća

\section{Introduction}

Biocomposites are the materials composed of particular phases on the basis of organic materials or they combine organic materials - phases with inorganic phases [1]. Biocomposites belong among materials which develop in a progressive way, however, a biological essence of the material comes against some restrictions. Nowadays, biomaterials find their application also in areas such as automotive industry [1]. Areas for growing Jatropha curcas L. (J. C.) are areas in South Asia, Africa and Central and South America. Seeds of these plants are pressed. Oil is gained which is utilizable in many industrial branches from health services to the production of biodiesel [2]. Conditions for pressing of the seeds and optimization of the pressing process are described by many authors [3]. During the pressing process commodities (biomass) come secondarily into being, in various forms according to requirements of the pressed oil - whole seeds above all are used for the pressing but Ruzbarsky et al. [4] state that the seed kernels are pressed only in case of high requirements for obtained oil (the application in the health services). One of the possibilities of using this biomass is biocomposite systems [5]. It is possible to use biomass of J. C. not only in the biocomposites. Another possibility for using the seed cake is feeding to animals, however, there is a problem with the presence of phorbol ester, a toxic constituent, which restricts the cake use in animal food [6]. Another possibility is utilization as a source of energy. Composite systems with the epoxy matrix can be also filled with the oil alone gained from the seeds of J. C. Gogoi et al. [7] describe properties of composite prepared from J.C. oil based on an alkyd and epoxy resin with different weight percentage of expanded graphite (EG), when significant improving in thermal mechanical properties was observed at $5 \mathrm{wt} \%$ of E. G. Shivamurthy et al. [2] ascertained in their experiment the strength and stiffness values also increased with the addition of J. C. seed cake particulate $(36,6 \mu \mathrm{m})$ to the epoxy matrix.

Another utilization of J. C. cake is stated by Hidayat et al. [8], who described properties and the utilization of this raw material as a raw material for binderless boards with properties, which are very similar to properties of commonly used particle boards. Sathees Kumar [9] evaluated the effect of the incorporation of J. C. oil cake alone and in combination with silicon carbide $(\mathrm{SiC})$ on the mechanical and tribological wear behaviour of glass fabric-epoxy (GE) composites - the incorporation of J. C. seed cake did not show any negative effect on the tensile strength of GE composites. The observed hardness was low in the filled composite compared to that of the unfilled GE composite. Biocomposites with J.C. particles also became more water resistant than the neat epoxy matrix at filler loading of 30 and $40 \mathrm{wt} \%$. Elshaarani et al. [10] describe in their experiments lower water uptake of composites based on Jatropha deoiled cake (JOC) and medium density polyethylene. As it is visible many authors describe a considerable influence of the biofiller presence from the plant J. C. on various properties of polymeric materials. The hypothesis about a good 
interaction between the epoxide and these fillers is judged from this

The paper focuses on a description of adhesive and cohesive properties of the epoxy resin filled with organic particle fillers of milled and sieve analysis sorted biomass obtained during pressing of J. C. seed (seed cake, seed kernel cake) and seed shells which were gained before pressing of the kernels alone. Tensile strength is used for the description of the cohesive characteristics, the adhesive characteristics are described by means of shear strength on steel adherents. These characteristics are completed with hardness and wear test.

\section{Material and Methods}

A polymeric material (reactoplastics) - the epoxy resin Glue Epox Rapid (Sincolor, s.c., Czech Republic) with high liquidity and increased speed of hardening was used as the matrix for the biocomposites (component A: Low-Molecular resin, component B: Polyamidic hardener, density $\left.1,15 \mathrm{~g} / \mathrm{cm}^{3}\right)$. Epoxy resins can be cast into forms which correspond to relevant standards by their shapes. They are suitable for filling with inorganic as well as organic fillers, as well as fibres. Cohesive and adhesive characteristics, which are created by the mutual interaction of phases, can be ranked among important properties. The concentration of filler in the epoxy matrix is described by volume percentage, because of the different density of resin and fillers $\left(0,54\right.$ to $\left.0,89 \mathrm{~g} / \mathrm{cm}^{3}\right)$. Test specimens were made in the whole possible range of concentrations, i.e. $10 \div 30 \%$. Higher than $30 \%$ concentration is already causing saturation of resin by filler, which deteriorates the workability and application possibilities.

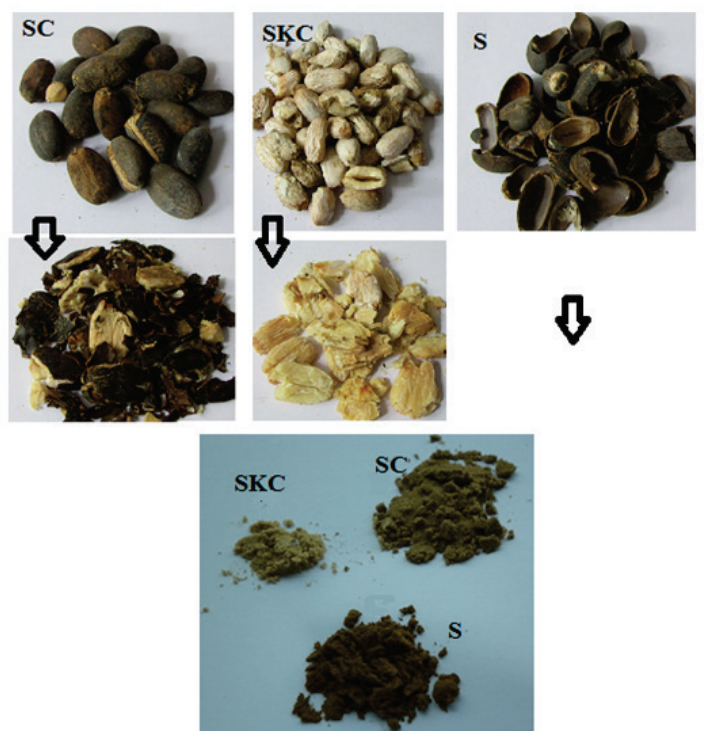

Figure 1 Fillers and their preparation - from top: original commodity, secondarily arisen product after pressing (it was not at shells), milled and sieve sorted particles (S-Shells, SC-Seed Cakes, SKC-Seed Kernel Cakes)

The pressing was carried out in a machine Labor Tech MP Test $5.0505 \mathrm{kN}$, deformation speed corresponded to $10 \mathrm{~mm} / \mathrm{min}$. The seed shells were divided from the kernel before pressing. The masses of the seeds used for the preparation of the micropowder were analysed - analytic scales $0,01 \mathrm{mg}$. The powder was always dried before the application into the epoxide and humidity of the micropowder was set. The resin was filled with the particle filler - milled and subsequently dimensionally sorted microparticles of the biomass obtained during pressing of the seeds and with the shells of the seeds divided before pressing of J. C. kernels (harvested in Indonesia). Particularly it was the shells of the seeds, the pressed kernels of the seeds and the seed oil cake (the pressed kernels also with the shells), see Fig. 1. A knife mill (20 000 turns/min) was used for milling of these commodities. The dimensional analysis was performed on the sieves $150 \mu \mathrm{m}$, subsequently the particular distribution size of the particles was determined with the stereoscopic microscope.

No agents for supporting the interphase adhesion were used. The resin was always filled in the interval 0 $30 \mathrm{wt} \%$. The filler was mechanically mixed into it and the mixture was subsequently hardened according to technological requirements of the producer. Mixing was carried out at temperature $24 \pm 2{ }^{\circ} \mathrm{C}$, relative humidity ranged from $40 \div 50 \%$. Mechanical mixing time $-2 \mathrm{~min}$ was adapted to processability of mixture $(6 \div 10 \mathrm{~min})$. The test samples were cast. A two-component silicone rubber with zero adhesion to cast mixtures was used for the production of forms for the test samples.

The hardness of test specimens was measured by the method Shore D - CSN EN ISO 868 (on specimens of sizes $35 \times 25 \times 9 \mathrm{~mm})$. Cast test specimens for the description of the cohesive properties (the tensile strength) according to the standard CSN EN ISO 3167 (Plastics - Multipurpose test specimen) were destructive tested in accordance with the standard CSN EN ISO 527 1 (Determination of tensile properties). The standard CSN EN 1465 (Determination of tensile lap-shear strength of rigid-to rigid bonded assemblies) was used for the description of adhesive properties to the steel adherent. The tests were performed using the steel S235J0 specimens of dimensions $100 \times 25 \times 1,5 \mathrm{~mm}$. The surfaces of $1,5 \mathrm{~mm}$ thick steel specimens were at first blasted using the synthetic corundum of the fraction F80 under the angle of $90^{\circ}$. The distance of the nozzle from the specimen during blasting corresponded to $2 \mathrm{~cm}$, blasting time of one sample area $\left(500 \mathrm{~mm}^{2}\right)$ corresponded to approximately one minute. Degreasing of specimens took place after blasting and cleansing in perchlorethylene bath. In this way the average surface roughness of $\mathrm{Ra}=$ $1,64 \pm 0,39 \mu \mathrm{m}$ was reached (see Fig. 2). The thickness of the gap between adherents was defined by used filler and by a viscosity of the system before crosslinking. No distance methods were used, neither at the composites nor at the unfilled resin.

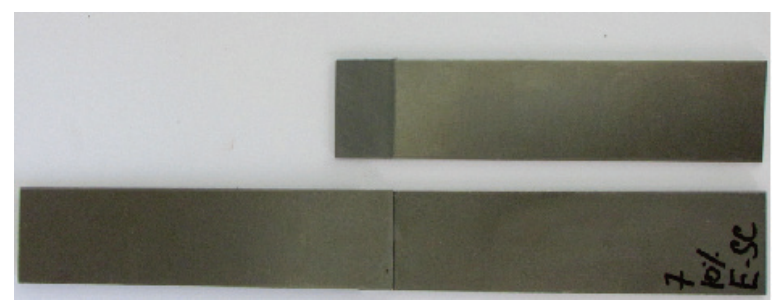

Figure 2 Prepared surface of sheet of steel, prepared for putting composite (above), overlapped test specimen (bottom) 
Then the surface was cleaned and degreased using acetone and prepared to the application. The surface preparation is important and should guarantee good strength on the boundary of the adherent and systems [11, 12]. An even thickness of the adhesive layer was reached by a constant pressure $0,5 \mathrm{MPa}$. The lapping was according to the standard $12,5 \pm 0,25 \mathrm{~mm}$. The failure type according to ISO 10365 was determined at the adhesive bonds. Tests were performed using the universal tensile strength testing machine LABTest 5.50ST $(50 \mathrm{kN})$.

The two-body abrasion was tested on a rotating cylindrical drum device with the abrasive cloth of the grain size $\mathrm{P} 220\left(\mathrm{Al}_{2} \mathrm{O}_{3}\right.$ grains $)$ according to the standard CSN 62 1466. The tested sample is in the contact with the abrasive cloth and it covers the distance of $60 \mathrm{~m}$. The time during which the specimen comes into contact with the abrasive cloth corresponds to 150 seconds. During one drum turn of $360^{\circ}$ it is provoked the tested sample left above the abrasive cloth surface. Consequent impact of the tested sample simulates the concussion. The pressure force is $10 \mathrm{~N}$. The mean of the tested samples was $15,5 \pm$ $0,1 \mathrm{~mm}$ and their height was $20,0 \pm 0,1 \mathrm{~mm}$.

\section{Results}

An average mass of the seeds (calculated from the mass of 100 seeds) amounted to $0,6549 \pm 0,1093 \mathrm{~g}$ at the ratio of the kernel mass to the shell mass $1: 0,59$. Particle fillers sorted by the sieve analysis were optically analysed on the stereoscopic microscope. Microparticle fillers were dried before the application into the epoxy resin - at $105^{\circ} \mathrm{C}$ for 20 hours. The humidity was set as the ratio of masses of $100 \mathrm{~g}$ particles before drying and after drying. The humidity of particular particles was recorded. Properties of the microparticles (see Tab. 1) are key for an interphase boundary - they define the strength of the interphase links.

Density of filled epoxy resins falls to the interval 0,94 $\div 1,14 \mathrm{~g} / \mathrm{cm}^{3}$. The porosity of these systems did not exceed $10 \%$.

The hardness of the biocomposites was reviewed by the method Shore D and by a modification of the hardness according to Brinell. The results of the measurements are graphically presented in Fig. 3. The inclusion of the microparticles biofiller led to the fall of the hardness values at the composites on the basis of E-SC and E-SKC. Only the system E-S showed higher values of the hardness than the unfilled resin. It did not come to a rise of high standard deviations during measuring of the hardness - a variation coefficient of the hardness measuring ranged to $2 \%$.
Filled epoxy resins can find their application in the area of the material engineering - constructional materials - various fibres are mostly the fillers. As far as the epoxy resin is saturated by the particle filler, this material is used as wear resistant above all (mostly abrasive, erosive). The utilization of relatively soft bioparticles of $\mathrm{J}$. C. is not suitable for these types of the wear (the adhesive wear only is worth considering), so that is why it is possible to look on these materials as on the materials serving for adhesive bonding and cementing or filled epoxides can serve as filling etc. The adhesive and cohesive characteristics above all of these biocomposites are important from this point of view. The cohesive characteristic is defined by the tensile strength, the adhesive characteristic is tested by the shear tensile strength on adherent defined in advance (Tab. 2).

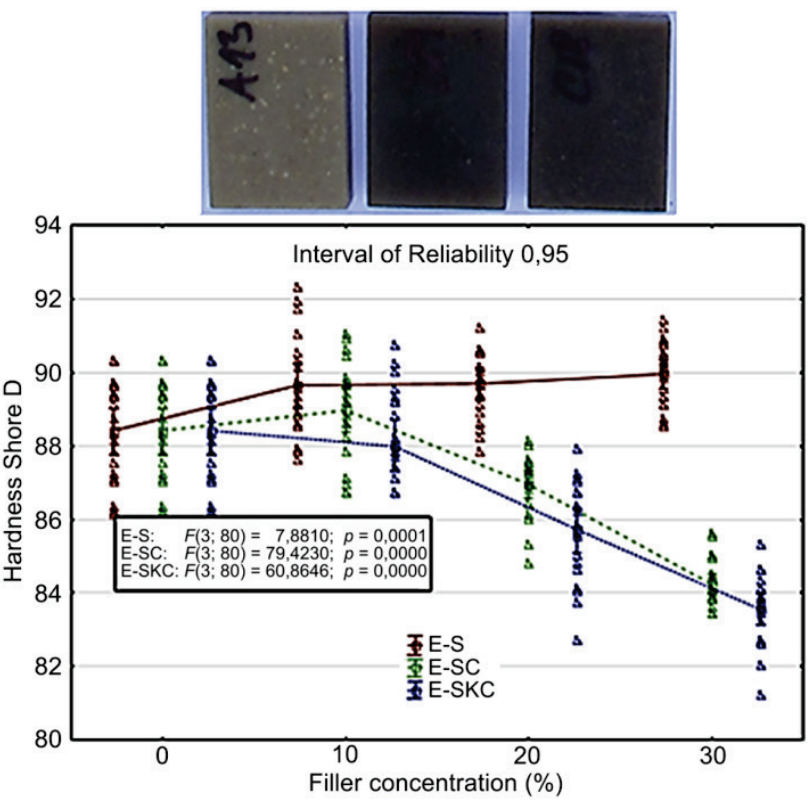

Figure 3 Hardness ShoreD, test samples

The adhesive failure type always occurred at the shear tensile strength. The gap between the adherents has always been defined by a composite system (there were no methods used for defining the gap). In the case of composite systems, the gap width was increasing with increasing concentration of filler and ranged in diameter between 0,44 to $0,53 \mathrm{~mm}$ (gap width was measured on stereoscopic microscope). So the mutual cohesion between the composite and the steel adherent was not perfect (the cohesive failure would occur). The cohesive strength was reviewed on test samples cast from the composite mixture (Fig. 4 right). Typical tensile diagrams are presented in the following graphs - Fig. 4 .

Table 1 Characterization of Composites

\begin{tabular}{|l|c|c|c|c|}
\hline \multicolumn{1}{|c|}{ Material (Description) } & Specimen code & $\begin{array}{c}\text { Particle size } \\
(\mu \mathrm{m})\end{array}$ & $\begin{array}{c}\text { Coefficient of } \\
\text { variation }(\%)\end{array}$ & $\begin{array}{c}\text { Particles humidity } \\
(\%)\end{array}$ \\
\hline Epoxy-shells & E-S & 67,8 & 35,0 & 8,3 \\
\hline Epoxy-seed cakes & E-SC & 108,1 & 50,4 & $0,54 \pm 0,14$ \\
\hline Epoxy-seed kernel cakes & E-SKC & 82,7 & 34,3 & 6,5 \\
\hline
\end{tabular}


Table 2 Mechanical characteristics of biocomposites based on J. C.

\begin{tabular}{|c|c|c|c|c|c|c|c|c|c|c|}
\hline \multirow{2}{*}{ Properties } & \multirow{2}{*}{$0 \%$} & \multicolumn{3}{|c|}{ E-S } & \multicolumn{3}{|c|}{ E-SC } & \multicolumn{3}{|c|}{ E-SKC } \\
\hline & & $10 \%$ & $20 \%$ & $30 \%$ & $10 \%$ & $20 \%$ & $30 \%$ & $10 \%$ & $20 \%$ & $30 \%$ \\
\hline Shear tensile strength $(\mathrm{MPa})$ & 11,31 & 7,42 & 7,39 & 7,02 & 6,57 & 4,59 & 3,52 & 6,34 & 4,39 & 3,29 \\
\hline Standard deviation $(\mathrm{MPa})$ & 0,86 & 1,08 & 0,89 & 0,39 & 0,70 & 0,17 & 0,51 & 0,29 & 0,71 & 0,28 \\
\hline Tensile strength $(\mathrm{MPa})$ & 49,95 & 46,36 & 37,17 & 31,34 & 45,07 & 35,44 & 26,33 & 42,68 & 33,37 & 25,77 \\
\hline Standard deviation $(\mathrm{MPa})$ & 1,56 & 2,24 & 1,84 & 1,75 & 2,61 & 1,42 & 2,55 & 2,01 & 1,61 & 1,83 \\
\hline Elongation at fracture $(\%)$ & 3,56 & 5,26 & 3,63 & 3,25 & 5,21 & 4,34 & 3,69 & 4,80 & 3,51 & 2,77 \\
\hline Standard deviation $(\%)$ & 0,41 & 0,33 & 0,36 & 0,14 & 0,29 & 0,23 & 0,57 & 0,45 & 0,38 & 0,37 \\
\hline
\end{tabular}

Table 3 Statistical comparison T-Test; $\mathrm{H}_{0}: \mu_{1}=\mu_{2}(p>0,05)$

\begin{tabular}{|c|c|c|c|c|c|c|c|c|c|}
\hline \multirow{3}{*}{ Compared sets } & \multicolumn{9}{|c|}{ Filler concentration $(\%)$} \\
\hline & \multicolumn{3}{|c|}{ Hardness } & \multicolumn{3}{|c|}{ Lap-shear strength } & \multicolumn{3}{|c|}{ Tensile strength } \\
\hline & 10 & 20 & 30 & 10 & 20 & 30 & 10 & 20 & 30 \\
\hline E-S/E-SC & 0,09 & 0,00 & 0,00 & 0,14 & 0,00 & 0,00 & 0,01 & 0,12 & 0,00 \\
\hline E-S/E-SKC & 0,00 & 0,00 & 0,00 & 0,06 & 0,00 & 0,00 & 0,42 & 0,00 & 0,00 \\
\hline E-SC/E-SKC & 0,03 & 0,00 & 0,00 & 0,48 & 0,51 & 0,96 & 0,10 & 0,06 & 0,69 \\
\hline
\end{tabular}
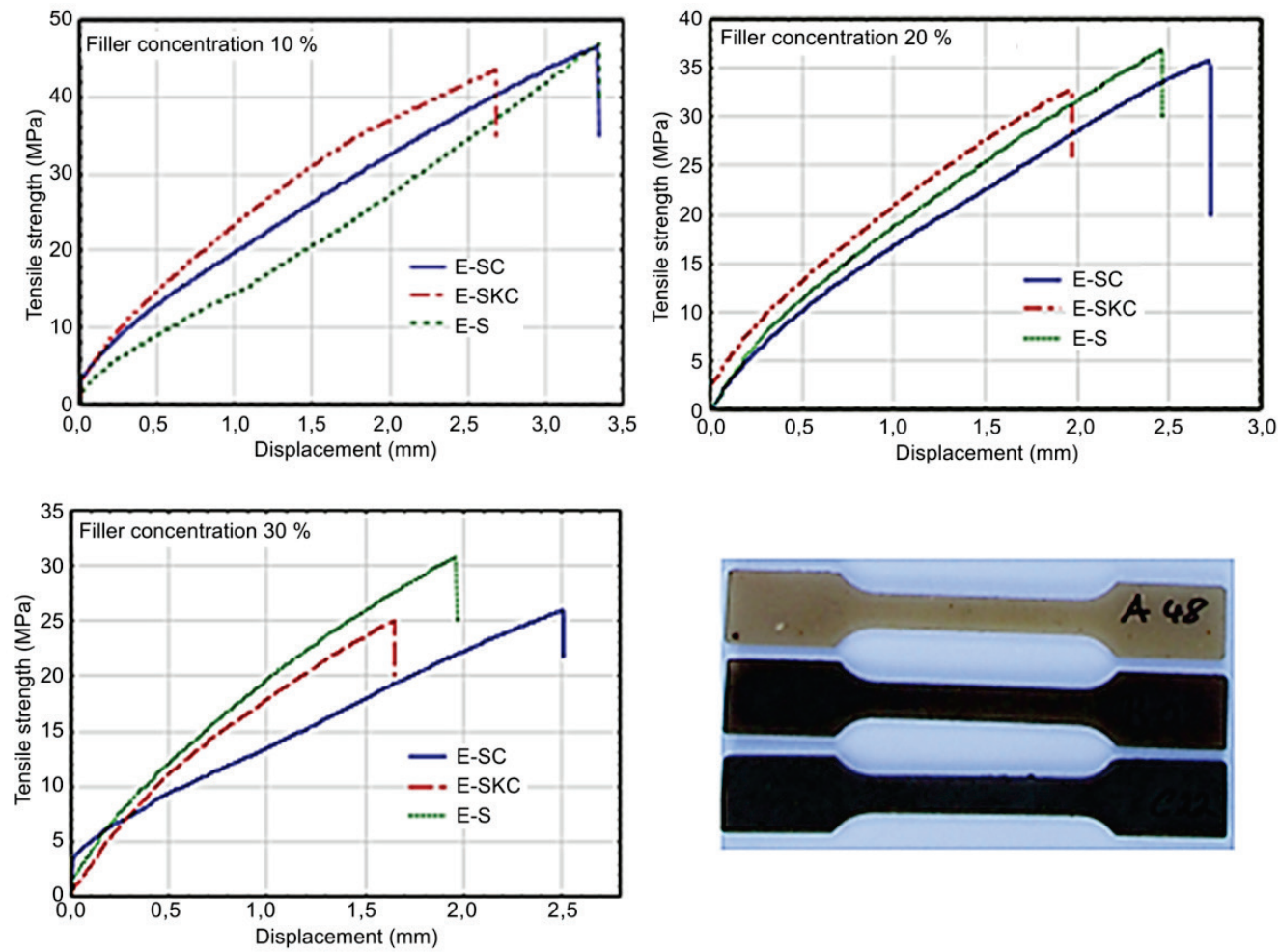

Figure 4 Tensile diagrams from top $10 \%, 20 \%, 30 \%$, cast test samples

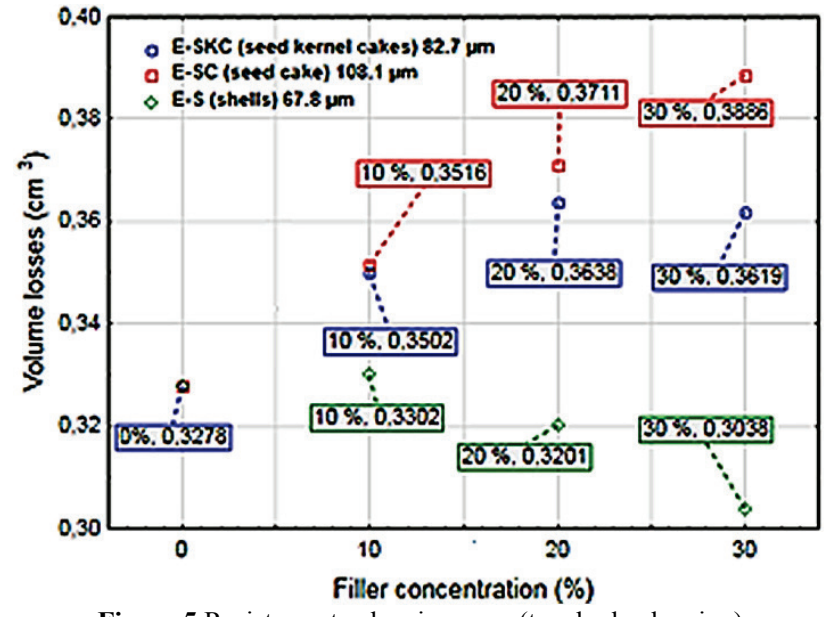

Figure 5 Resistance to abrasive wear (two body abrasion)

A statistical comparison of chosen mechanical properties of composites with different type of the biofiller on the basis of J. C. made by means of ANOVA
(T-test) is stated in the following Tab. 3. A zero hypothesis $\mathrm{H}_{0}(p>0,05)$ specifies that there is no statistically significant difference among tested sets from the mean value point of view. It is obvious from the statistical comparison that the composites E-SC and ESKC show similar adhesive and cohesive characteristics and this is in the whole tested interval $0 \div 30 \%$ fillers in the matrix. The mean values of hardness data sets are statistically different.

Volume losses of filled epoxy resin are shown in Fig. 5. In this case of E-SC and E-SKC systems the volume losses grew in comparison with non-filled resin (maximum increase of $18,5 \%$ ). In case of the E-S biocomposites the smallest volume loss has been measured on system with $30 \%$ of filler (the decrease of volume loss of 7,3\% - compared with non-filled resin. Temperature of the interface of worn areas of test samples was measured during abrasion wear by noncontact laser thermometer - average temperature reached value of 36,1 $\pm 3,7^{\circ} \mathrm{C}$. 


\section{Discussion}

A described way of using bioparticles is an alternative to other types of the utilization - such as the energic utilization described by Christodoulou et al. [13]. The differences among particular types of the filler based on the microparticles from the plant J. C. were proved. Bioparticle fillers do not always have comparable properties as opposed to inorganic types of the fillers and powders from the seeds in the interaction with the polymer are topics of researches [14]. Complex properties of commodities, which are used for the preparation of biofillers, can be only brought near to intervals required in advance (the humidity). However, e.g. a chemical composition of J. C. seeds and their oiliness differ depending on a harvesting place - see the work of Gao et al. [15] who state a hyperspectral image technique as a method for defining the seed origin. $\mathrm{Wu}$ et al. [16] state e.g. the optimum content of water in the kernel $3 \%$ (an optimal process of screw-pressing) - all these factors influence the subsequently prepared particle biofiller and properties of the biocomposites on the basis of J. C. It is necessary to respect this at the interpretation of results. Owing to high content of the oil in the seed the considerable choking of the sieve meshes occurred during the sieve analysis and the sieves had to be cleaned in short intervals. Natural fillers of the composites are renewable and the experiment confirmed the assumption of Williams and Wool [17] - the good interaction of the cohesive and adhesive characteristics of the epoxide to natural fillers when the mutual interaction was inexpensive and it led to the rise of new material with specific mechanical characteristics. The hardness of the epoxy resin changed proportionally with the filler amount. It came to the increase of the hardness of $1,7 \%$ at E-S composites. The fall of the hardness occurred at other composites - of $4,7 \%$ at E-SC and of $5,2 \%$ at E-SKC. Cohesive characteristics of the resin decreased at all types of the fillers. The lowest values showed the systems with $30 \%$ of the filler in the matrix comparing with the unfilled resin. The values were by $37 \%$ smaller at E-S composite, by $46,8 \%$ at E-SC and $48,4 \%$ at E-SKC. The fall was also recorded at the adhesive characteristics where it reached $38 \%$ (at E-S), $69 \%$ (at E-SC) and $71 \%$ (at E$\mathrm{SKC}$ ). The fall is not in accordance with the results of Shivamurthy et al. [2], who used J. C. seed cake particulate $(36,6 \mu \mathrm{m})$. The difference among values can be caused by the size of the particles and by the preparation of composites. Just casting, which was used, is prone to a rise of pores which were identified by the optical analysis. These pores lead to the fall of mechanical properties. Remaining presence of oil in the particles also influences the interaction among particles and epoxy resin, or the composite system and the adherent [18]. This fact showed up at composites E-SC and E-SKC. Inorganic types of the filler of similar size e.g. a glass powder or corundum $\left(\mathrm{Al}_{2} \mathrm{O}_{3}\right)$ also lower the cohesive characteristics, however in small concentration (to 15 vol.\%) they have similar shear strength like the unfilled resin. Just the presence of the oil in used fillers can decrease the interaction among phases.

\section{Conclusion}

From the compared fillers point of view the composites with the filler E-S (Epoxy/shells) showed the best cohesive and adhesive characteristics. Generally the conclusions from the experiment can be summed up in the following way:

- The hypothesis about the creation of the interphase interaction (J. C. filler and epoxide) was confirmed.

- The alternative for other utilizations of the waste from pressing J. C.

- The application with low costs - adhesive bonding, cementing, with lower mechanical requirements.

- Presupposed improvement of observed characteristics when using the vacuum (however, it would increase the costs for the preparation of composites).

- The potential for biodegradable plastics.

\section{Acknowledgements}

This paper has been done using the grant IGA TF (2015:31140/1312/3107 - Optimizing of the properties of resins and adhesives filled with organic and anorganic microparticles determined with experimental approach).

\section{References}

[1] Fowler, P. A. et al. Biocomposites: Technology, environmental credentials and market forces. // Journal of the Science of Food and Agriculture. 86, (2006), pp. 17811789. DOI: $10.1002 /$ jsfa.2558

[2] Shivamurthy, B., et al. Mechanical properties and sliding wear behavior of Jatropha seed cake waste/epoxy composites. // Journal of Material Cycles and Waste Management. 16, (2014), pp. 1-3.

[3] Herak, D. et al. Energy demands for pressing Jatropha curcas L. seeds. // Biosystems Engineering. 106, (2010), pp. 527-534. DOI: 10.1016/j.biosystemseng.2010.06.002

[4] Ruzbarsky, J. et al. Analysis of physical and mechanical properties and of gross calorific value of Jatropha curcas seeds and waste from pressing process. // Agronomy Research. 12, (2014), pp. 603-610.

[5] Khalil, H. P. S. A. et al. A Jatropha biomass as renewable materials for biocomposites and its applications. // Renewable and Sustainable Energy Reviews. 22, (2013), pp. 667-685. DOI: 10.1016/j.rser.2012.12.036

[6] Guedes, R. E. et al. Detoxification of Jatropha curcas seed cake using chemical treatment: Analysis with a central composite rotatable design. // Industrial Crops and Products. 52, (2014), pp. 537-543. DOl: 10.1016/j.indcrop.2013.11.024

[7] Gogoi, P. et al. Jatropha curcas oil based alkyd/epoxy resin/expanded graphite (EG) reinforced bio-composite: Evaluation of the thermal, mechanical and flame retardancy properties. // Progress in Organic Coatings. 77, (2014), pp. 87-93. DOI: 10.1016/j.porgcoat.2013.08.006

[8] Hidayat, H. et al. Preparation and properties of binderless boards from Jatropha curcas L. seed cake. Industrial Crops and Products. 52, (2014), pp. 245-254. DOl: 10.1016/j.indcrop.2013.10.024

[9] Satheesh, M. N. et al. Applications of Jatropha oil seed crop. // Recent Patents on Materials Science. 2, (2009), pp. 131-139. DOI: 10.2174/1874464810902020131

[10] Elshaarani, M. T. et al. Jatropha deoiled cake fillerreinforced medium-density polyethylene biocomposites: Effect of filler loading and coupling agent on the mechanical, dynamic mechanical and morphological 
properties. // Polymer Composites. 34, (2013), pp. 746-756. DOI: $10.1002 / p c .22479$

[11] Novak, M. Surface duality hardened steels after grinding. Manufacturing technology. 11, (2011), pp. 55-59.

[12] Rudawska, A. Selected aspects of the effect of mechanical treatment on surface roughness and adhesive joint strength of steel sheets. // International Journal of Adhesion and Adhesives. 50, (2014), pp. 235-243. DOI: 10.1016/j.jjadhadh.2014.01.032

[13] Christodoulou, C. et al. Circulating fluidized bed gasification tests of seed cakes residues after oil extraction and comparison with wood. // Fuel. 132, (2014), pp. 71-81. DOI: 10.1016/j.fuel.2014.04.012

[14] Mittal, V. et al. True biocomposites with biopolyesters and date seed powder: Mechanical, thermal, and degradation properties. // Journal of Applied Polymer Science. 131, 19(2014), 40186(pp. 1-15). DOI: 10.1002/app.40816

[15] Gao, J. et al. Application of hyperspectral imaging technology to discriminate different geographical origins of Jatropha curcas L. seeds. // Computers and Electronics in Agriculture. 99, (2013), pp. 186-193. DOl: 10.1016/j.compag.2013.09.011

[16] Wu, W. X. et al. Process optimization of cake oriented screw-pressing of Jatropha curcas. // Applied Mechanics and Materials. 130, (2012), pp. 3898-3903.

[17] Williams, G. J.; Wool, R. P. Composites from natural fibers and soy oil resins. // Applied Composite Materials. 7, (2000), pp. 421-432. DOI: 10.1023/A:1026583404899

[18] Samsuri, A.; Zoveidavianpoor, M. Does the Maturity of jatrophacurcas L. affect the quality and quantity of the yield of oil for biodiesel production? // International Journal of Green Energy. 11, (2014), pp. 193-205. DOI: $10.1080 / 15435075.2013 .772055$

\section{Authors' addresses}

Petr Valášek, Assoc. Prof. Ing., PhD

Department of Material Science and Manufacturing Technology, Faculty of Engineering, Czech University of Life Science,

Kamýcká 129, 16521 Prague, Czech Republic

E-mail: valasekp@tf.czu.cz

Miroslav Müller, Assoc. prof., Ing., $\mathrm{PhD}$

Department of Material Science and Manufacturing Technology,

Faculty of Engineering, Czech University of Life Science,

Kamýcká 129, 16521 Prague, Czech Republic

E-mail: muller@tf.czu.cz

Alessandro Ruggiero, Assoc. Prof. Ing., PhD

Department of Industrial Engineering

University of Salerno

Via Giovanni Paolo II, nr. 132

84084 Fisciano, Italy

E-mail: ruggiero@unisa.it 